Rev. Fac. Agron. (LUZ). 2021, 38(4): 846-866. Octubre-Diciembre.

DOI: https://doi.org/10.47280/RevFacAgron(LUZ).v38.n4.06

ISSN 2477-9407

\title{
Biometric characteristics of winter forage cereals grown under nitrogen fertilization in temperate rain conditions
}

Características biométricas de los cereales forrajes de invierno cultivados bajo fertilización con nitrógeno en condiciones de lluvia templada

Características biométricas dos cereais forrageiros de inverno crescidos sob fertilização com nitrogênio em condições de chuva temperada

\section{Muhammad Jamil ${ }^{1,2}$, Muhammad Ansar ${ }^{1}$, Zammurad Iqbal Ahmed $^{1}$, Tanveer Ahmed ${ }^{3}$, Muhammad Shehzad ${ }^{2 *}$,Aqeel $\mathrm{Ahmad}^{2}$ and Imran Mahmood ${ }^{1}$}

\begin{abstract}
${ }^{1}$ Department of Agronomy, Faculty of crop and food sciences, PMAS Arid Agriculture University Rawalpindi. Email: (MJ) mjamilrajaucr@gmail.com, (D); (MA) muhammad. ansar@uaar.edu.pk; (D);ZI) zammurad@hotmail.com, (D) (IM) imran403@uaar.edu.pk, (iD) ${ }^{2}$ Department of Agronomy, Faculty of Agriculture, University of Poonch Rawalakot. Email: (MS) m.shahzaduaf@gmail.com, (D); (AA) aqeelao878@gmail.com, (D). ${ }^{3}$ Department of Livestock Production and Management, Faculty of Veterinary and Animal Sciences, PMAS Arid Agriculture University Rawalpindi. Email: tanveer.ahmad@uaar.edu.pk, (D).
\end{abstract}

\section{Abstract}

The farmers of hilly areas face severe fodder shortage in winter season except to have only dry stalks of summer cereals. The study aimed to evaluate the adaptability of winter forage cereals (barley, oats, rye and triticale) and to quantify the suitable dose of nitrogen $\left(0,75,150\right.$ and $\left.225 \mathrm{~kg} \cdot \mathrm{ha}^{-1}\right)$ for the assessment of biometric and qualitative characteristics of winter forage cereals (WFCs) at booting stage (BS) and milking dough stage (MDS) grown under temperate conditions. Two years (2016-2017 and 2017-2018) field trials were executed at the University of Poonch Rawalakot, Pakistan. Harvested forage then preserved as silage by adding Formic acid and Molasses as additives at the rate of $5 \mathrm{~kg}^{-1} \mathrm{t}^{-1}$. Rye crop in conjunction with $225 \mathrm{~kg} \cdot \mathrm{ha}^{-1}$ nitrogen out yielded greater plant height which

Received: 02-12-2020 • Accepted: 24-02-2021.

*Corresponding autor. Email:m.shahzaduaf@gmail.com 
led to the highest green fodder (55413 and $43542 \mathrm{~kg}^{-h^{-1}}$ ) and dry matter yield (188471 and $12440 \mathrm{~kg} \cdot \mathrm{ha}^{-1}$ ) during consecutive years 2017 and 2018, respectively. Whereas, oats cultivar performed better for fresh weight, dry weight and leaf area per plant. More crude protein contents were recorded for triticale crop at N3 level with use of molasses during both the years at both cutting stages (booting and milking dough). More crude fibre was noted in barley crop at control level of nitrogen fertilization on both booting and milking dough stage. The correlation analysis revealed direct interrelationship among yield attributes and fodder yield of winter forage cereals and thus indicating the need to supply nitrogen at the rate of $225 \mathrm{~kg} \cdot \mathrm{ha}^{-1}$ for improving biometric characteristics of WFCs.

Keywords: yield, silage, nitrogen levels, winter forage cereals

\section{Resumen}

Los agricultores de las zonas montañosas se enfrentan a una grave escasez de forraje en la temporada de invierno, excepto para tener solo tallos secos de cereales de verano. El estudio tuvo como objetivo evaluar la adaptabilidad de los cereales forrajeros de invierno (cebada, avena, centeno y triticale) y cuantificar la dosis adecuada de nitrógeno $\left(0,75,150\right.$ y $\left.225 \mathrm{~kg} \cdot \mathrm{ha}^{-1}\right)$ para la valoración de características biométricas y cualitativas de cereales forrajeros de invierno (WFC) en fase de arranque (BS) y fase de grano lechoso (MDS) cultivados en condiciones templadas. Se llevaron a cabo pruebas de campo de dos años (2016-2017 y 20172018) en la Universidad de Poonch Rawalakot, Pakistán. El forraje cosechado luego se conserva como ensilado agregando ácido fórmico y melaza como aditivos a razón de $5 \mathrm{~kg} \cdot \mathrm{t}^{-1}$. El cultivo de centeno en conjunto con $225 \mathrm{~kg} \cdot \mathrm{ha}^{-1}$ de nitrógeno rindió mayor altura de planta lo que llevó a la mayor producción de forraje verde (55413 y $\left.43542 \mathrm{~kg} \cdot \mathrm{ha}^{-1}\right)$ y de materia seca (188471 y $\left.12440 \mathrm{~kg} \cdot \mathrm{ha}^{-1}\right)$ durante años 2017 y 2018, respectivamente. Considerando que, el cultivar de avena se comportó mejor en peso fresco, peso seco y área foliar por planta. Se registraron más contenidos de proteína cruda para el cultivo de triticale a nivel N3 con el uso de melaza durante ambos años en ambas etapas de corte (arranque y grano lechoso). Se observó más fibra cruda en el cultivo de cebada al nivel de control de fertilización con nitrógeno tanto en la etapa de arranque como en la etapa de grano lechoso. El análisis de correlación reveló una interrelación directa entre los atributos de rendimiento y el rendimiento de forraje de los cereales forrajeros de invierno, lo que indica la necesidad de suministrar nitrógeno a razón de 225 kg.ha-1 para mejorar las características biométricas de los WFC.

Palabras clave: rendimiento, ensilaje, niveles de nitrógeno, cereales forrajeros de invierno.

\section{Resumo}

Os agricultores de áreas montanhosas enfrentam severa escassez de forragem no inverno, exceto por terem apenas hastes secas de cereais de verão. $\mathrm{O}$ estudo 
teve como objetivo avaliar a adaptabilidade de cereais forrageiros de inverno (cevada, aveia, centeio e triticale) e quantificar a dose adequada de nitrogênio ( 0 , 75,150 e $225 \mathrm{~kg} \cdot \mathrm{ha}^{-1}$ ) para avaliação de características biométricas e qualitativas. de cereais forrageiros de inverno (WFCs) na fase de inicialização (BS) e fase de massa de ordenha (MDS) cultivadas em condições temperadas. Testes de campo de dois anos (2016-2017 e 2017-2018) foram executados na Universidade de Poonch Rawalakot, Paquistão. A forragem colhida e depois preservada como silagem pela adição de ácido fórmico e melaço como aditivos na taxa de $5 \mathrm{~kg}^{-\mathrm{t}^{-1}}$. A safra de centeio em conjunto com $225 \mathrm{~kg}$.ha-1 de nitrogênio gerou maior altura de planta, o que levou à maior forragem verde (55413 e $\left.43542 \mathrm{~kg} \cdot \mathrm{ha}^{-1}\right)$ e produção de matéria seca (188471 e 12440 kg.ha $\left.{ }^{-1}\right)$ durante anos de 2017 e 2018, respectivamente. Já a cultivar de aveia apresentou melhor desempenho para massa fresca, massa seca e área foliar por planta. Mais teores de proteína bruta foram registrados para a cultura do triticale no nível de N3 com uso de melaço durante ambos os anos em ambas as fases de corte (booting e massa de ordenha). Mais fibra bruta foi observada na cultura da cevada no nível de controle da fertilização com nitrogênio, tanto na fase de inicialização quanto na fase de ordenha da massa. A análise de correlação revelou uma inter-relação direta entre os atributos de produção e a produção de forragem de cereais forrageiros de inverno e, portanto, indicando a necessidade de fornecimento de nitrogênio na proporção de $225 \mathrm{~kg} \mathrm{ha}^{-1}$ para melhorar as características biométricas de WFCs.

Palavras-chave: rendimento, silagem, níveis de nitrogênio, cereais forrageiros de inverno

\section{Introduction}

Forages performance in Azad Jammu and Kashmir, Pakistan, always remained despondent because of weather regimes and generation of farm based knowledge. Major elements underlying this inactive performance comprise the slow proportion of scientific invention, development, and inadequate attention towards livestock feeding issues (Govt. of Pakistan, 2017-18). Livestock is a fundamental constituent of agriculture subdivision as $30-35 \%$ of rural inhabitants of the country are endorsed in livestock enterprises especially in dryland agriculture. The demand for milk, butter, meat, beef, and their by-

\section{Introducción}

El rendimiento de forrajes en Azad Jammu y Kashmir, Pakistán, permanecieron afectados negativamente por los regímenes climáticos y la generación de conocimientos basados en la explotación. Los principales elementos que subrayan este rendimiento inactivo comprenden la lenta proporción de la invención científica, el desarrollo y la atención inadecuada hacia los problemas de alimentación del ganado (Gobierno de Pakistán, 2017-18). La ganadería es un componente fundamental de la subdivisión de la agricultura, ya que entre el 30 y el $35 \%$ de los habitantes de las zonas rurales del país están respaldados por empresas ganaderas, 


\section{Rev. Fac. Agron. (LUZ). 2021, 38(4):846-866. Octubre-Diciembre.}

products is rising due to rapidly growing population. In Pakistan, animals are mainly deficiency in protein and energy intake (Khan et al., 2014). Animal performance depends on fodder intake, digestibility, and nutrient utilization efficiency (Lekgari et al., 2008). Conventionally summer browsing and cereal stubble nutrition in winter are the foremost sources of feed for livestock which is nutritionally poor to maintain the health and productivity of animals (Mut et al., 2015). Livestock contributes $58.9 \%$ to agriculture value addition, while it contributes $11.1 \%$ to the national GDP (Govt. of Pakistan, 2018).

Forage crops in agriculture need a lot of attention for sustainable livestock production. Consistent fodder production is a fundamental prerequisite for boosting the livestock industry in Pakistan. Fodder production is limited because of low fertility of soil, non-availability of improved forage varieties in rainfed regions of the country (Iqbal et al., 2009). The shortage of green fodder during the winter season is even more severe and farmers have no option to feed their animals on dry stalks of summer cereals and grasses in these areas. Therefore, to improve forage production is the need of time to meet the increasing fodder supplies in dryland situations. Different agronomic factors affect yield and quality of forage the most important factor is growth stage of plant at harvest (Mut et al., 2006). The quantity and quality of forage are affected by several factors such as type of crop and cutting especialmente en la agricultura de secano. La demanda de leche, mantequilla, carne, carne de res y sus subproductos está aumentando debido al rápido crecimiento de la población. En Pakistán, los animales presentan deficiencias principalmente en el consumo de proteínas y energía (Khan et al., 2014). El rendimiento de los animales depende de la ingesta de forraje, la digestibilidad y la eficiencia en la utilización de nutrientes (Lekgari et al., 2008). El pastoreo convencional en verano y la alimentación con rastrojos de cereales en invierno son las principales fuentes de alimentación para el ganado, que es nutricionalmente pobre para mantener la salud y la productividad de los animales (Mut et al., 2015). La ganadería contribuye en un 58,9\% al valor añadido de la agricultura, mientras que contribuye en un 11,1\% al PIB nacional (Gobierno de Pakistán, 2018).

Los cultivos de forraje en la agricultura necesitan mucha atención para una producción ganadera sostenible. La producción constante de forraje es un requisito fundamental para impulsar la industria ganadera en Pakistán. La producción de forraje es limitada ya que existe una baja fertilidad de los suelos, y existe falta de disponibilidad de variedades de forraje mejoradas en las regiones de secano del país (Iqbal et al., 2009).

La escasez de forraje verde durante la temporada de invierno es aún más severa y los agricultores no tienen otra opción de alimentar a sus animales con los tallos secos de cereales y las hierbas de verano de estas zonas. Por 


\section{Rev. Fac. Agron. (LUZ). 2021, 38(4):846-866. Octubre-Diciembre.}

stage. Agronomic inputs and their application are considered critical to optimize total dry matter yield. Mineral fertilizer including nitrogen is an important energy resource for forage production, and provides essential mineral nutrition for crop growth and development ( $\mathrm{Li}$ et al., 2016). Furthermore, nitrogen is the topmost limiting nutrient for crop rising in dry areas thus efficient $\mathrm{N}$ management strategies often result in large economic benefits to farmers (Worku et al., 2007). Nitrogen is the most important component affecting crop canopy and its growth rate. It is a foremost component in attaining regularly high yields in cereal forages being constituent of many fundamental cell components such as nucleic acids, amino acids, enzymes, and photosynthetic pigments (Amanullah et al., 2008). To maintain green fodder production at a profitable level, it is important to achieve higher use efficiency of nitrogenous fertilizers through proper application (Mut et al., 2006). Barley and oats crop too have testified their performance as forage crop in rainfed region of Azad Jammu and Kashmir, but the potential of rye and triticale cereals is yet required to be explored in these situations (Anwar et al., 2010). In stress environment, it helps crops in establishment and provides forage for longer period of time by delaying maturity. Keeping under consideration the significance of different winter forage cereal crops such as oats, barley, rye and triticale, the present study was carried out to grow these forages at different lo tanto, mejorar la producción de forraje es la necesidad del momento para satisfacer el creciente suministro de forraje en situaciones de secano. Los diferentes factores agronómicos afectan al rendimiento y la calidad del forraje, siendo el factor más importante la etapa de crecimiento de la planta en el momento de la cosecha (Mut et al., 2006). La cantidad y la calidad del forraje se ven afectadas por varios factores tales como el tipo de cultivo y la etapa de corte. Los insumos agronómicos y su aplicación se consideran críticos para optimizar el rendimiento total de la materia seca. Los fertilizantes minerales, incluido el nitrógeno, son un recurso energético importante para la producción de forraje, y proporcionan una nutrición mineral esencial para el crecimiento y desarrollo de los cultivos (Li et al., 2016). Además, el nitrógeno es el nutriente más limitante para el crecimiento de los cultivos en las zonas secas, por lo que las estrategias de gestión eficiente del $\mathrm{N}$ suelen reportar grandes beneficios económicos para los agricultores (Worku et al., 2007). El nitrógeno es el componente más importante que afecta la cubierta vegetal y su tasa de crecimiento. Es un componente primordial para lograr rendimientos regularmente elevados en los cereales de forrajes, al ser constituyente de muchos componentes celulares fundamentales como ácidos nucleicos, aminoácidos, enzimas y pigmentos fotosintéticos (Amanullah et al., 2008). Para mantener la producción de forraje verde a un nivel rentable, es importante alcanzar una mayor 
Rev. Fac. Agron. (LUZ). 2021, 38(4):846-866. Octubre-Diciembre.

Jamil et al.

ISSN 2477-9407

nitrogen regimes under temperate conditions with the objectives to a) identify the suitable winter forage cereal and its cutting stage for higher yield under temperate conditions, b) Standardize the amount of nitrogenous fertilizer for winter forage cereals and c) to reduce the protein loss during ensiling by adding different preservatives.

\section{Materials and methods}

\section{Experimental site description}

The research was carried out at the University of Poonch Rawalakot, Azad Jammu and Kashmir, Pakistan (33.85 ${ }^{\circ} \mathrm{N}$, $73.76^{\circ} \mathrm{E}$ ) which is located at an altitude of 1638 meters (Zafar et al., 2013). The study was executed during spring season of 2017 and 2018. The soil of the experimental area is classified as Thermic Lithic Eutrudepts, while it has temperate climate as per Koppen classification scheme (Geiger, 1954). The experimental area receives an annual precipitation of about 700 $800 \mathrm{~mm}$, while mean temperature remains $5-28^{\circ} \mathrm{C}$ (Khaliq and Abbasi, 2015). A pre-sowing physicochemical analysis revealed that soil of the experimental block was of silt-loam type, while it was slightly of alkaline nature with $\mathrm{pH}$ of around 8. It contains $\mathrm{P} 5.4 \mathrm{mg} \cdot \mathrm{kg}^{-1}$, K 130 mg.kg ${ }^{-1}$ and EC 1.08 dS.m ${ }^{-1}$. It was also found to be rich in organic matter (7\%).

\section{Detail of experiment}

Treatments included four winter forage cereals i.e. Barley, eficiencia en el uso de fertilizantes nitrogenados mediante una aplicación adecuada (Mut et al., 2006). Los cultivos de cebada y avena también han demostrado su rendimiento como cultivos de forraje en las zonas de secano de Azad Jammu y Kashmir, pero el potencial de los cereales de centeno y triticale aún debe ser explorado en estas situaciones (Anwar et al., 2010). El estrés ambiental, ayuda a los cultivos a establecerse y proporciona forraje para periodos de tiempo más largos al retrasar la madurez. Tomando en cuenta la importancia de los diferentes cultivos de cereales forrajeros de invierno tales como, la avena, la cebada, el centeno y el triticale, el presente estudio se llevó a cabo para evaluar estos forrajes en diferentes regímenes de nitrógeno bajo condiciones templadas con los objetivos de: a) identificar el cereal forrajero de invierno adecuado y su fase de corte para obtener un mayor rendimiento en condiciones templadas, b) estandarizar la cantidad de abono nitrogenado para los cereales forrajeros de invierno y c) reducir la pérdida de proteína durante el ensilado añadiendo diferentes conservantes.

\section{Materiales y métodos}

\section{Descripción del sitio experimental}

La investigación se llevó a cabo en la Universidad de Poonch Rawalakot, Azad Jammu y Kashmir, Pakistán $\left(33,85^{\circ} \mathrm{N}, 73,76^{\circ} \mathrm{E}\right)$ la cual se encuentra localizada a una altitud de 1638 metros (Zafar et al., 2013). El estudio 
Rev. Fac. Agron. (LUZ). 2021, 38(4):846-866. Octubre-Diciembre.

Jamil et al.

ISSN 2477-9407

Oats, Rye and Triticale and four nitrogen levels $(0,75,150$ and 225 $\left.\mathrm{kg} \cdot \mathrm{ha}^{-1}\right)$. The experiment was laid out in the factorial arrangement of randomized complete block design (RCBD) and was replicated thrice. The net plot size was maintained at $12 \mathrm{~m}^{2}$. The crops were harvested at $\mathrm{BS}$ and MDS, while harvested forage was preserved in silage form for three weeks by adding folic acid and molasses as preservatives.

\section{Crop management}

In order to prepare a fine seed bed, the experimental block was ploughed thrice using tractormounted plough. Each ploughing was followed by planking using a wooden plank to pulverize the soil. Planting of crops was carried out with hand drill at a row spacing of $22.5 \mathrm{~cm}$. The recommended dose of mineral phosphorus (50 kg.ha-1 elemental P) and Potassium (25 $\mathrm{kg} \cdot \mathrm{ha}^{-1}$ elemental K) were applied in the form single super phosphate and sulphate of potassium. Nitrogen was applied as per treatment in the form of urea. All the fertilizers were applied as basal dose. Approved seed rate of $80 \mathrm{~kg} \cdot \mathrm{ha}^{-1}$ was used for sowing of barley, oats and triticale while rye crop was sown at the rate of 40 kg.ha ${ }^{-1}$. The non-experimental area was maintained around the experimental block where respective crop was broadcasted.

\section{Data Recordings}

Following observations were noted from experiment at the time of booting and milking se realizó durante la temporada de primavera de 2017 y 2018 . El suelo del área experimental se clasifica como Eutrudepts lítico térmico, mientras que tiene un clima templado según el esquema de clasificación de Koppen (Geiger, 1954). El área experimental recibe una precipitación anual de alrededor de 700-800 mm, mientras que la temperatura media permanece entre $5-28^{\circ} \mathrm{C}$ (Khaliq y Abbasi, 2015). Un análisis físico-químico previo a la siembra reveló que el suelo del área experimental fue de tipo limo-arenoso, mientras que era de naturaleza ligeramente alcalina, con un $\mathrm{pH}$ de alrededor de 8. Este contiene P 5,4 mg.kg-1, K 130 mg.kg ${ }^{-1}$ y CE 1,08 dS. $\mathrm{m}^{-1}$. También se encontró que era rico en materia orgánica (7\%).

\section{Detalles del experimento}

Los tratamientos incluyeron cuatro cereales forrajeros de invierno tales como, la cebada, la avena, el centeno y el triticale, y cuatro niveles de nitrógeno (0, 75, 150 y 225 kg.ha-1). $\mathrm{El}$ experimento se realizó mediante un diseño de bloques completamente al azar (DBCA) y se repitió tres veces. El tamaño de la parcela neta se mantuvo en $12 \mathrm{~m}^{2}$. Los cultivos se cosecharon en BS y MDS, mientras que el forraje cosechado se conservó en forma de ensilado durante tres semanas añadiendo ácido fólico y melaza como conservantes.

\section{Manejo del cultivo}

Con el fin de preparar una cama de semilla fina, el terreno experimental fue arado tres veces con un arado montado en un tractor. Cada arada iba seguida de un cepillado con una tabla de madera para pulverizar el suelo. La 
Rev. Fac. Agron. (LUZ). 2021, 38(4):846-866. Octubre-Diciembre.

Jamil et al.

ISSN 2477-9407

dough stage. For measuring all agronomic traits quadrate thrown randomly in each experimental plot. Plant height $(\mathrm{cm})$, fresh weight plant ${ }^{-1}(\mathrm{~g})$, dry weight. plant $^{-1}$ (g), green fodder yield $\left(\mathrm{kg} \cdot \mathrm{ha}^{-1}\right)$ and dry matter yield (kg.ha ${ }^{-1}$ ) were recorded. Dry matter yield was documented after drying of plants in oven (Nabertherm TR-450) at $65^{\circ} \mathrm{C}$ for 48 hours. Fresh samples were dried in oven till constant weight than finally weighed and converted into kg.ha-1 with the use of Kern EMB portable balance. Likewise, leaf area of ten randomly selected plants from each plot was detailed at both stages with the usage of leaf area meter model no. (Ci202) and average was noted. The chopped fodder was preserved as silage by adding folic acid and molasses as preservative. Crude protein (\%) and crude fibre (\%) were also determined through standard procedure (AOAC, 2012)

\section{Statistical analysis}

The recorded data were subjected to analysis of variance technique using statistical software package "Statistix 8.1 version" (Steel et al., 1997). The significance of the treatment means was determined by using Tukey's Honest Significant test at $5 \%$ level of probability

\section{Results and discussions}

Significant $(\mathrm{p} \leq 0.05)$ interaction was observed between crops and nitrogen levels for agronomic plantación de los cultivos se realizó con un taladro manual con una separación entre hileras de $22,5 \mathrm{~cm}$. Se aplicaron las dosis recomendadas de fósforo mineral (50 kg.ha-1 de P elemental) y de potasio ( $25 \mathrm{~kg} \cdot \mathrm{ha}^{-1}$ de $\mathrm{K}$ elemental) en forma de superfosfato simple $\mathrm{y}$ sulfato de potasio. El nitrógeno se aplicó como un tratamiento en forma de urea. Todos los fertilizantes se aplicaron como dosis basal. Para la siembra de cebada, avena y triticale se utilizó una cantidad de semilla certificada de 80 kg.ha ${ }^{-1}$, mientras que el cultivo de centeno se sembró a una dosis de $40 \mathrm{~kg} \cdot \mathrm{ha}^{-1}$. El área no experimental se mantuvo alrededor del bloque experimental donde se sembró el cultivo respectivo.

\section{Registro de datos}

En el experimento se realizaron observaciones tomando las medidas en fases de arranque y de grano lechoso. Para medir todas las características agronómicas se arrojaron cuadrados al azar en cada parcela experimental. Se registró la altura de la planta $(\mathrm{cm})$, el peso fresco de la planta ${ }^{-1}$ (g), el peso seco de la planta $^{-1}(\mathrm{~g})$, el rendimiento del forraje verde $\left(\mathrm{kg} \cdot \mathrm{ha}^{-1}\right)$ y el rendimiento de la materia seca (kg.ha $\left.{ }^{-1}\right)$. El rendimiento de la materia seca se documentó después del secado de las plantas en un horno (Nabertherm TR-450) a $65^{\circ} \mathrm{C}$ por 48 horas. Las muestras frescas se secaron en el horno hasta alcanzar un peso constante y luego se pesaron y se convirtieron en kg.ha-1 con el uso de la balanza portátil Kern EMB. Asimismo, se detalló el área foliar de diez plantas seleccionadas al azar de cada parcela en ambas etapas 
Rev. Fac. Agron. (LUZ). 2021, 38(4):846-866. Octubre-Diciembre.

Jamil et al.

ISSN 2477-9407

and yield related traits at booting and milking stage during both years of study (2016-17 and 2017-18) (Tables 1, 2). Interactive effect of $\mathrm{N}_{3} \mathrm{C}_{3}$ was superior for plant height during 2016-17 but remained at par in 2017-18 at both booting and milking dough stages. It was probably a genetically controlled character and got affected by various factors such as seed vigour and soil conditions. This study corroborate with the results of Kim et al. (2017), who verified that among small grain winter cereals, rye and triticale produced more forage yield as a result of more number of plant, profuse tillers and taller plants, especially in low temperature environments, because of its comparatively low temperature requirements for growth as well as distinct cold stress tolerance. Similarly, nitrogen is also important nutrient which affects growth attributes like plant height, number of tillers, these results are in continuity with Gangwar and Lodhi (2018) who reported that biometric expressions were affected by disparity among nitrogen levels, in terms of main shoot height and number of tillers.plant ${ }^{-1}$. The results of this experiment was in agreement with Ahmad et al. (2011) who stated that tillers. palnt ${ }^{-1}$ and plant height of forage oat was significantly affected by different levels of nitrogen fertilizer. con el uso del medidor de área foliar modelo $\mathrm{N}^{\circ}$ (Ci-202) y se anotó la media. El forraje picado se conservó como ensilado añadiendo ácido fólico y melaza como conservante. También se determinaron la proteína cruda (\%) y la fibra cruda (\%) mediante el procedimiento estándar (AOAC, 2012)

\section{Análisis estadístico}

Los datos registrados fueron sometidos a la técnica de análisis de varianza utilizando el paquete de software estadístico Statistix versión 8.1 (Steel et al., 1997). La significación de las medias de los tratamientos se determinó utilizando la prueba de Tukey a un nivel de probabilidad del $5 \%$.

\section{Resultados y discusión}

Se observó una interacción significativa $(p \leq 0,05)$ entre los cultivos y los niveles de nitrógeno para las características agronómicas, relacionadas con el rendimiento en las etapas de arranque y grano lechoso durante los dos años de estudio (2016-17 y 2017-18) (Cuadros 1, 2). El efecto de la interacción de $\mathrm{N}_{3} \mathrm{C}_{3}$ fue superior para la altura de la planta durante 2016-17, pero se mantuvo a la par en 2017-18 tanto en las etapas de arranque como de grano lechoso. Probablemente, se trata de un carácter controlado genéticamente y se ve afectado por diversos factores como el vigor de la semilla y las condiciones del suelo. Este estudio corrobora los resultados de Kim et al. (2017), quienes verificaron que entre los cereales de invierno de grano pequeño, el centeno y el triticale produjeron más rendimiento de forraje, como resultado 
Rev. Fac. Agron. (LUZ). 2021, 38(4):846-866. Octubre-Diciembre. Jamil et al.

ISSN 2477-9407

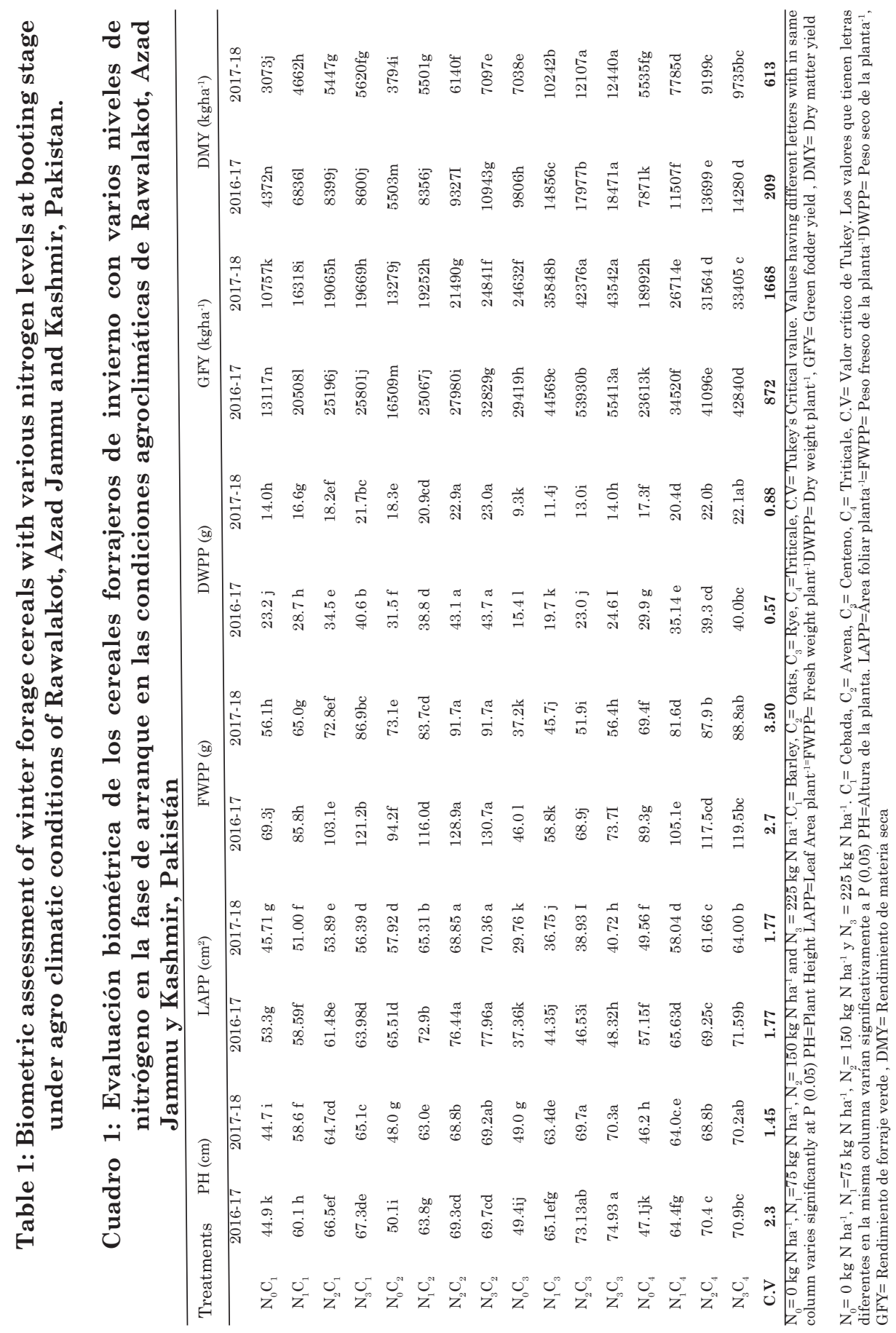




\section{Rev. Fac. Agron. (LUZ). 2021, 38(4):846-866. Octubre-Diciembre.}

Jamil et al.

ISSN 2477-9407

Similar results were reported by Li et al. (2010) and mentioned that increase in nitrogen up to $300 \mathrm{~kg} \cdot \mathrm{ha}^{-1}$ improved plant height in wheat crop. Possible justification for this could be rate of nitrogen in refining growth features of crop plant. Although oat $\left(\mathrm{C}_{2}\right)$ having more fresh weight, dry weight and leaf area per plant with $\mathrm{N}_{3}\left(225 \mathrm{~kg} \mathrm{~N} \cdot \mathrm{ha}^{-1}\right)$ remained inferior in yield than Rye $\left(\mathrm{C}_{3}\right)$ at $\mathrm{BS}$ and MD stage during both the years. Oat crop fertilized with $\mathrm{N}_{2}(150 \mathrm{~kg}$ N.ha ${ }^{-1}$ ) showed non-significant difference from $\mathrm{N}_{3}$ for fresh weight, dry weight and leaf area per plant. This might be due to more assimilates of photosynthesis. The results of present study are consistence with those of Bilal et al. (2017) who confirmed that plant morphological parameters, fresh weight, dry weight was most receptive to nitrogen fertilization and every successive rise in nitrogen dose expressively produced taller plants oat forage crop. Nitrogen boosts meristem and photosynthetic efficacy by regulating up the cell elongation, division and chlorophyll substances of leaves and it reflects the higher DMY. Furthermore, observation of these findings was in contrast with Zhang et al. (2017) who reported that chemical $\mathrm{N}$ fertilizer input increased soil water recharge, grain yield and WUE as well, but no further increases were observed when $\mathrm{N}$ rate exceeded 75 or $150 \mathrm{~kg} \mathrm{~N} \cdot \mathrm{ha}^{-1}$ in most cases of winter wheat. These results are also coincides with the observations of Ahmad et al. (2011) who reported that there was a substantial effect of inorganic sources of fertilizers on de un mayor número de plantas, macollas profusas y plantas más altas, especialmente en entornos de baja temperatura, debido a sus requisitos de temperatura comparativamente bajos para el crecimiento, así como a su distinta tolerancia al estrés por frío. De igual forma, el nitrógeno es también un nutriente importante que afecta los atributos de crecimiento tales como la altura de la planta y el número de tallos; estos resultados están en concordancia con lo reportado por Gangwar y Lodhi (2018), quienes reportaron que las expresiones biométricas se vieron afectadas por la disparidad entre los niveles de nitrógeno, en términos de la altura del brote principal y el número de macollas.planta ${ }^{-1}$. Los resultados de este experimento coinciden con Ahmad et al. (2011), quienes afirmaron que la altura de las macollas.planta ${ }^{-1}$ y la altura de la planta de avena forrajera se vieron significativamente afectadas por diferentes niveles de fertilizante nitrogenado.

Se reportaron resultados similares por Li et al. (2010) y mencionaron que el aumento de nitrógeno hasta 300 $\mathrm{kg} \cdot \mathrm{ha}^{-1}$ mejoró la altura de la planta en el cultivo de trigo. Una posible justificación para esto podría ser la tasa de nitrógeno en el perfeccionamiento de las características de crecimiento de la planta de cultivo. Aunque la avena $\left(\mathrm{C}_{2}\right)$ tuvo más peso fresco, peso seco y área foliar por planta con $\mathrm{N}_{3}$ (225 kg N.ha $\left.{ }^{-1}\right)$ siguió siendo inferior en rendimiento que el centeno $\left(\mathrm{C}_{3}\right)$ en la etapa BS y MDS durante ambos años. El cultivo de avena fertilizado con $\mathrm{N}_{2}\left(150 \mathrm{~kg}\right.$ N.ha $\left.{ }^{-1}\right)$ no mostró diferencias significativas con respecto 


\section{Rev. Fac. Agron. (LUZ). 2021, 38(4):846-866. Octubre-Diciembre.}

number of leaves per plant in forage oat that ultimately leads to higher leaf area. The data for green fodder yield and dry matter yield exhibited maximum value in $\mathrm{N}_{3} \mathrm{C}_{3}$ that was followed by $\mathrm{N}_{2} \mathrm{C}_{3}$ in $2016-17$, whereas at par in 2017-18 at Booting stage. Moreover, at milking dough stage green fodder and dry matter yield was found utmost in $\mathrm{N}_{3} \mathrm{C}_{3}$ compared to rest of the treatments, followed by $\mathrm{N}_{2} \mathrm{C}_{3}$ during consecutive years.

The plants supplied with premier dose of nitrogen bear more leaves and therefore, produced the highest leaf to stem ratio which leads to maximum green fodder yield. In contrast to our findings Khan et al. (2014) documented that under the agro climatic conditions of Sargodha, Pakistan, the higher yields of fodder in oat can be probably accredited to their greater leaf area, responsible for more photosynthetic efficacy, having high aptitude to hoard assimilative products of photosynthesis. Winter forage cereals were significantly different for their DMY could be the possible reason for those WFCs has different relative performance for biometric growth characters results are in accordance with Tawfiq and Muhammed (2014) whereas, Geren (2014) reported difference in DMY of winter cereals was due to encroachment in growth stage. As harvesting of winter cereals was delayed DMY increased considerably. Kim

et al. (2017) examined significant difference between mean and temporal forage yield among winter cereals under different climatic conditions rye and triticale produced a $\mathrm{N}_{3}$ en cuanto a peso fresco, peso seco y área foliar por planta. Esto podría deberse a un mayor número de asimilados de la fotosíntesis. Los resultados del presente estudio coinciden con aquellos reportados por Bilal et al. (2017) quienes confirmaron que los parámetros morfológicos de la planta, el peso fresco y el peso seco, fueron los más receptivos a la fertilización nitrogenada y que cada aumento sucesivo de la dosis de nitrógeno producía plantas más altas en el cultivo forrajero de avena. El nitrógeno aumenta el meristemo y la eficacia fotosintética al regular la elongación celular, la división y las sustancias clorofílicas de las hojas y refleja el mayor DMY. Además, la observación de estos resultados contrasta con la de Zhang et al. (2017), quienes informaron que el aporte de fertilizantes químicos de $\mathrm{N}$ aumentó la recarga de agua del suelo, el rendimiento del grano y el WUE, pero no se observaron más aumentos cuando la tasa de $\mathrm{N}$ superó los 75 o $150 \mathrm{~kg} \mathrm{~N} \cdot \mathrm{ha}^{-1}$ en la mayoría de los casos de trigo de invierno. Estos resultados también coinciden con las observaciones de Ahmad et al. (2011), quienes informaron que hubo un efecto sustancial de las fuentes inorgánicas de fertilizantes en el número de hojas por planta en la avena forrajera que, en última instancia, conduce a una mayor área foliar. Los datos de rendimiento de forraje verde y rendimiento de materia seca mostraron el valor máximo en $\mathrm{N}_{3} \mathrm{C}_{3}$ que fue seguido por $\mathrm{N}_{2} \mathrm{C}_{3}$ en 2016-17, mientras que a la par en 2017-18 en la etapa de arranque. Además, en la 
Rev. Fac. Agron. (LUZ). 2021, 38(4):846-866. Octubre-Diciembre. Jamil et al.

ISSN 2477-9407

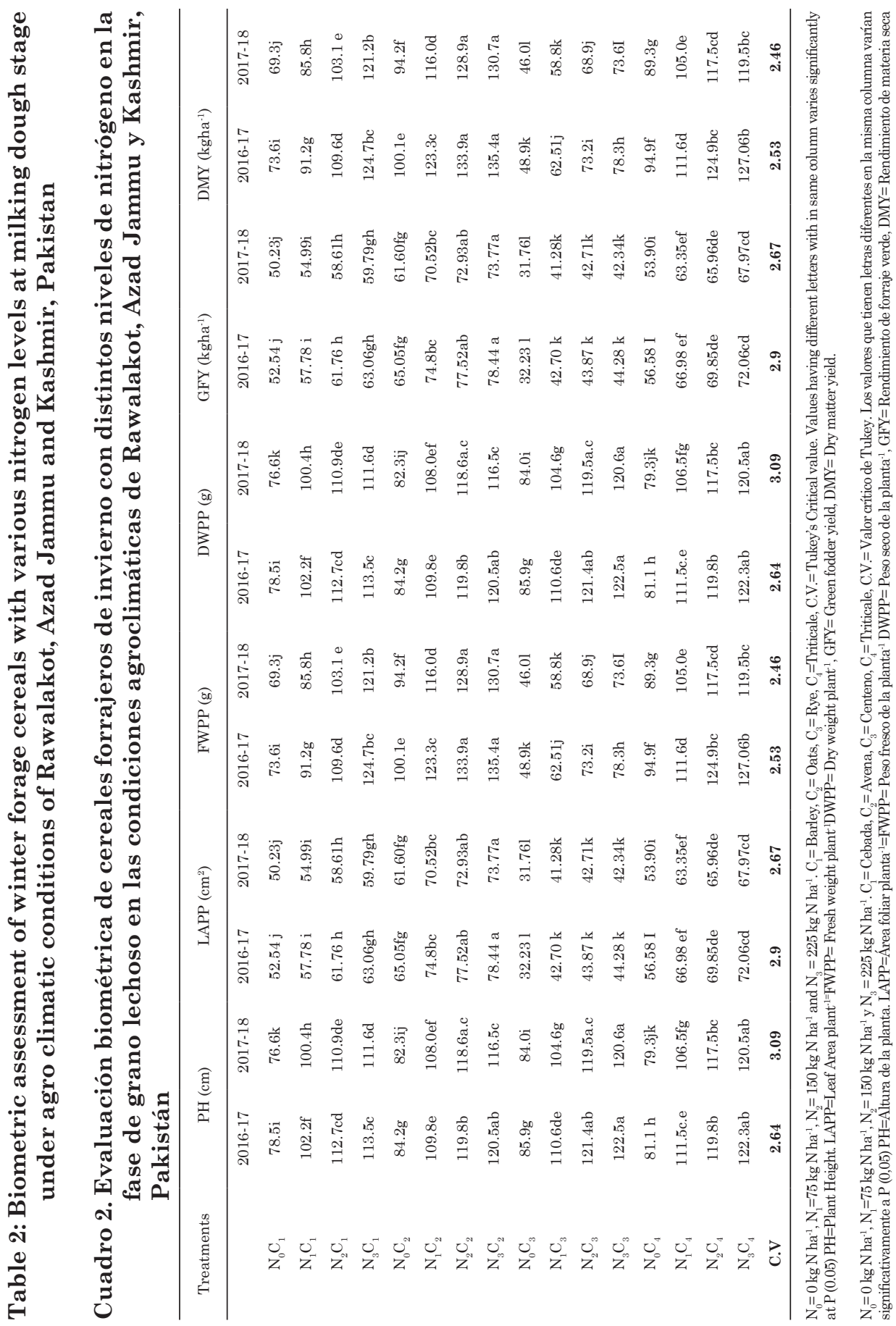




\section{Rev. Fac. Agron. (LUZ). 2021, 38(4):846-866. Octubre-Diciembre.}

more forage yield than oats and wheat during and across the season. Crude protein is the most essential component for estimating the quality of silage especially in WFCs (Ronga et al. 2020). During both the years at different locations all the WFCs at various NLs proved differences among each other for crude protein contents. During both the years extreme values of $\mathrm{CP}$ contents were recorded for triticale crop at $\mathrm{N}_{3}$ level of $\mathrm{N}$ with use of molasses at both harvesting stages (Table 3). Triticale is a hybrid of wheat and rye, which inherited the ability of rye to survive under severe drought conditions, but has higher protein value than rye (Glamočlija et al., 2018). Crude protein increases with progression in growing stage of winter cereals which is in accordance with Geren (2014). Similarly, Li et al. (2016) confirmed that crude protein content of wheat silage was increased significantly with increasing $\mathrm{N}$ up to $225 \mathrm{~kg}$.ha-1, while they no longer increased at $\mathrm{N}$ up to 300 kg.ha ${ }^{-1}$. Furthermore, Obour et al. (2018) testified that CP contents of oat forage were passively increased with the increment of nitrogen application rate. The aerobic stability of high moisture winter cereal silages was linearly increased with the application rate of chemical additives. Malik et al. (2015) stated that high CP content at early vegetative stage was due to more leafy and luscious nature of plant at this stage. Dhillon et al. (2019) recognized that CP content was decreased with increase in age of crop plant. Landry et al. (2019) reported that winter cereal cover crops such fase de grano lechoso, el rendimiento de forraje verde y de materia seca fue mayor en $\mathrm{N}_{3} \mathrm{C}_{3}$ en comparación con el resto de los tratamientos, seguido de $\mathrm{N}_{2} \mathrm{C}_{3}$ durante los años consecutivos

Las plantas tratadas con dosis de nitrógeno de primer nivel tienen más hojas y, por lo tanto, producen la mayor relación hoja/tallo, lo que conduce a un máximo rendimiento de forraje verde. En contraste con nuestros hallazgos, Khan et al. (2014) reportaron que bajo condiciones agroclimáticas de Sargodha, Pakistán, los mayores rendimientos de forraje en la avena pueden deberse probablemente a su mayor área foliar, responsable de una mayor eficacia fotosintética, teniendo una alta aptitud para acaparar productos asimilables de la fotosíntesis. Los cereales forrajeros de invierno fueron significativamente diferentes para su DMY, podría ser la posible razón por la que esos WFC tienen un rendimiento relativo diferente para los caracteres biométricos de crecimiento. Los resultados están de acuerdo con Tawfiq y Muhammed (2014) mientras que, Geren (2014) informó que la diferencia en DMY de los cereales de invierno fue debido a la sobrepoblación en la etapa de crecimiento. A medida que se retrasa la cosecha de los cereales de invierno, el DMS aumenta considerablemente. Kim et al. (2017) determinaron diferencias significativas entre rendimiento medio y temporal del forraje entre los cereales de invierno bajo diferentes condiciones climáticas; el centeno y el triticale produjeron más rendimiento de forraje que la avena y el trigo durante y a lo largo de la temporada. La proteína cruda es el 


\section{Rev. Fac. Agron. (LUZ). 2021, 38(4):846-866. Octubre-Diciembre.}

\section{Jamil et al.}

as wheat, rye and triticale as spring forage shown significant increase in $\mathrm{CP}$ values with the increment of $\mathrm{N}$ rates while on other hand $\mathrm{CP}$ contents were decreased as the advancement of growth from flag leaf stage to heading stage. Barley crop was ahead of other cereal crops for crude fibre, while lowest value of crude fibre was noted in rye crop (Table 3). Crude fibre decreases when the level of nitrogen increases. Silage preserved by adding molasses remained higher for crude fibre analysis during both the years and at both harvesting stages. Results of these findings were in line with Li et al. (2016) and Surber et al. (2011) who confirmed that with increasing rate of $\mathrm{N}$ application $\mathrm{CF}$ contents of whole wheat crop silage was decreased. Furthermore, Morais et al. (2017) the use of chemical additives are justified to improve aerobic stability of high moisture cereal silages. The graph displayed linear increase for numbers of plants with green fodder yield showing positive correlation, depicting that taller plants have the potential to yield higher biomass.

Furthermore, association between plant height and number of tillers with green fodder yield presented in Figure 1 also exhibited positive linear correlation among each other with fresh fodder yield indicating the need to breed forage varieties having higher potential for crop plant height and tillers.plant ${ }^{-1}$. The individual relationship showed strongly positive while cumulative relationship with nitrogen doses showed moderate association among variables. values of our correlation componente más esencial para estimar la calidad del ensilado, especialmente en los WFC (Ronga et al. 2020). Durante los dos años y en las diferentes localizaciones, todos los WFC en varios NL demostraron diferencias entre sí en cuanto al contenido de proteína cruda. En ambos años se registraron valores extremos de contenido de PC en el cultivo de triticale con el nivel de $\mathrm{N}_{3}$ y el uso de melaza en ambas etapas de la cosecha (Cuadro 3). El triticale es un híbrido de trigo y centeno, que heredó la capacidad del centeno para sobrevivir en condiciones de sequía severa, pero tiene mayor valor proteico que el centeno (Glamočlija et al., 2018). La proteína cruda aumenta con la progresión en la fase de crecimiento de los cereales de invierno, lo que coincide con Geren (2014). Del mismo modo, Li et al. (2016) confirmaron que el contenido de proteína cruda del ensilado de trigo se incrementó significativamente con el aumento de $\mathrm{N}$ hasta $225 \mathrm{~kg} \cdot \mathrm{ha}^{-1}$, mientras que ya no aumentó con $\mathrm{N}$ hasta 300 kg.ha-1. Además, Obour et al. (2018) atestiguaron que los contenidos de PC del forraje de avena se incrementaron pasivamente con el aumento de la tasa de aplicación de nitrógeno. La estabilidad aeróbica de los ensilados de cereales de invierno de alta humedad se incrementó linealmente con la tasa de aplicación de aditivos químicos. Malik et al. (2015) afirmaron que el alto contenido de PC en la etapa vegetativa temprana se debió a la naturaleza más frondosa y exuberante de la planta en esta etapa. Dhillon et al. (2019) reconocieron que el contenido de $\mathrm{PC}$ disminuía con el aumento de la edad 
Rev. Fac. Agron. (LUZ). 2021, 38(4):846-866. Octubre-Diciembre.

Jamil et al.

ISSN 2477-9407

Table-3: Crude protein and Crude Fiber (\%) content in preserved silage of winter forage cereals at booting and milking dough stage grown under varying nitrogen levels during 2016-17 and 201718 at Rawalakot, Azad Jammu and Kashmir, Pakistan

Cuadro 3. Contenido de proteína cruda y Fibra cruda (\%) en el ensilado conservado de cereales forrajeros de invierno en la fase de arranque y de grano lechoso cultivados bajo diferentes niveles de nitrógeno durante 2016-17 y 2017-18 en Rawalakot, Azad Jammu y Kashmir, Pakistán.

\begin{tabular}{|c|c|c|c|c|c|c|c|c|c|c|c|c|c|c|c|c|c|}
\hline \multirow[t]{2}{*}{ 突 } & \multirow[t]{2}{*}{ 糡 } & \multicolumn{4}{|c|}{ CP-BS (2016-17) } & \multicolumn{4}{|c|}{ CP-MDS (2016-17) } & \multicolumn{4}{|c|}{ CF-BS (2016-17) } & \multicolumn{4}{|c|}{ CF-MDS (2016-17) } \\
\hline & & $\mathrm{N}_{0}$ & $\mathrm{~N}_{1}$ & $\mathrm{~N}_{2}$ & $\mathrm{~N}_{3}$ & $\mathrm{~N}_{0}$ & $\mathrm{~N}_{1}$ & $\mathrm{~N}_{2}$ & $\mathrm{~N}_{3}$ & No & N1 & $\mathrm{N} 2$ & N3 & No & N1 & $\mathrm{N} 2$ & N3 \\
\hline \multirow{4}{*}{ E } & Con & 9.0 & 10.1 & 10.8 & 11.0 & 6.9 & 7.9 & 8.6 & 8.8 & 29.9 & 29.1 & 28.3 & 27.8 & 31.7 & 31.6 & 30.8 & 30.4 \\
\hline & FA & 9.1 & 10.2 & 10.9 & 11.1 & 7.0 & 8.0 & 8.7 & 8.9 & 29.2 & 29.1 & 28.3 & 27.9 & 31.7 & 31.6 & 30.9 & 30.4 \\
\hline & Mol & 9.2 & 10.3 & 11.0 & 11.2 & 7.1 & 8.1 & 8.8 & 9.0 & 29.2 & 29.7 & 28.9 & 28.5 & 32.4 & 32.2 & 31.5 & 31.0 \\
\hline & Con & 9.4 & 9.9 & 10.1 & 10.7 & 7.2 & 7.7 & 8.0 & 8.5 & 28.3 & 27.4 & 25.7 & 24.4 & 30.8 & 30.0 & 28.3 & 27.1 \\
\hline \multirow[t]{3}{*}{ 刃ิ } & FA & 9.5 & 10.0 & 10.4 & 11.2 & 7.4 & 7.8 & 8.2 & 9.0 & 28.3 & 27.5 & 25.7 & 24.4 & 30.9 & 30.0 & 28.3 & 27.1 \\
\hline & Mol & 9.6 & 10.0 & 10.4 & 11.2 & 7.4 & 7.8 & 8.3 & 9.1 & 28.9 & 28.1 & 26.2 & 24.9 & 31.5 & 30.6 & 28.9 & 27.6 \\
\hline & Con & 9.7 & 10.0 & 10.8 & 10.9 & 7.6 & 7.8 & 8.6 & 8.7 & 23.1 & 22.8 & 22.5 & 21.1 & 25.8 & 25.5 & 25.3 & 23.9 \\
\hline \multirow[t]{3}{*}{$\Re$} & FA & 9.8 & 10.1 & 10.9 & 11.0 & 7.7 & 7.9 & 8.7 & 8.8 & 23.1 & 22.8 & 22.3 & 21.2 & 25.9 & 25.5 & 25.1 & 24.0 \\
\hline & Mol & 9.9 & 10.2 & 11.0 & 11.1 & 7.7 & 8.0 & 8.8 & 8.9 & 23.6 & 23.3 & 22.2 & 20.8 & 26.3 & 26.0 & 25.0 & 23.6 \\
\hline & Con & 9.7 & 10.1 & 10.9 & 11.1 & 7.6 & 7.9 & 8.7 & 8.9 & 26.2 & 26.0 & 24.5 & 24.1 & 28.9 & 28.7 & 27.1 & 26.8 \\
\hline \multirow[t]{3}{*}{ J゙ } & FA & 9.8 & 10.2 & 11.0 & 11.2 & 7.7 & 8.0 & 8.8 & 9.0 & 26.3 & 26.1 & 24.5 & 24.1 & 28.9 & 28.7 & 27.2 & 26.8 \\
\hline & Mol & 9.9 & 10.2 & 11.1 & 11.3 & 7.8 & 8.1 & 8.9 & 9.1 & 26.8 & 26.6 & 25.0 & 24.7 & 29.4 & 29.3 & 27.7 & 27.3 \\
\hline & \multicolumn{5}{|c|}{ (2017-18) } & \multicolumn{4}{|c|}{$(2017-18)$} & \multicolumn{4}{|c|}{$(2017-18)$} & \multicolumn{4}{|c|}{ (2017-18) } \\
\hline \multirow{4}{*}{$\vec{J}$} & Con & 9.1 & 9.5 & 9.9 & 10.1 & 7.9 & 8.9 & 9.5 & 9.8 & 28.4 & 28.2 & 27.5 & 27.0 & 31.7 & 31.6 & 30.8 & 30.4 \\
\hline & FA & 9.5 & 9.6 & 10.0 & 10.3 & 8.0 & 9.0 & 9.6 & 9.9 & 28.4 & 27.9 & 27.5 & 26.8 & 31.7 & 31.5 & 30.8 & 30.4 \\
\hline & Mol & 9.8 & 10.2 & 10.6 & 10.8 & 8.1 & 9.1 & 9.7 & 10.0 & 29.0 & 28.9 & 28.1 & 27.6 & 32.3 & 32.2 & 31.4 & 31.0 \\
\hline & Con & 8.3 & 9.4 & 10.2 & 110 & 6.7 & 7.6 & 8.0 & 8.3 & 27.6 & 26.6 & 24.8 & 23.5 & 30.8 & 30.0 & 28.3 & 27.0 \\
\hline \multirow[t]{3}{*}{ ঠิ } & FA & 8.7 & 9.8 & 10.6 & 11.4 & 7.3 & 7.7 & 8.1 & 8.4 & 27.7 & 26.6 & 24.8 & 23.5 & 30.8 & 30.0 & 28.3 & 27.0 \\
\hline & Mol & 8.9 & 10.0 & 10.9 & 11.6 & 7.0 & 7.6 & 8.1 & 8.4 & 28.1 & 27.2 & 25.4 & 24.1 & 31.4 & 30.6 & 28.8 & 27.5 \\
\hline & Con & 11.8 & 12.2 & 12.9 & 13.2 & 8.6 & 8.8 & 9.6 & 10.0 & 22.3 & 21.9 & 21.7 & 20.3 & 24.8 & 24.5 & 23.5 & 22.1 \\
\hline \multirow[t]{3}{*}{ 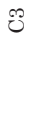 } & FA & 11.9 & 12.6 & 13.3 & 13.5 & 8.7 & 8.9 & 9.7 & 9.7 & 22.3 & 22.0 & 21.5 & 20.4 & 24.9 & 24.5 & 23.5 & 22.1 \\
\hline & Mol & 11.5 & 12.9 & 13.6 & 13.3 & 8.7 & 9.0 & 9.8 & 9.8 & 22.9 & 22.4 & 21.3 & 20.0 & 25.3 & 25.0 & 24.0 & 22.6 \\
\hline & Con & 9.8 & 10.6 & 11.4 & 12.6 & 8.6 & 8.9 & 9.6 & 9.9 & 25.4 & 24.2 & 23.6 & 22.3 & 28.8 & 28.6 & 27.1 & 26.8 \\
\hline \multirow[t]{2}{*}{ త゙ } & FA & 10.8 & 11.4 & 12.3 & 13.0 & 8.7 & 9.0 & 9.7 & 10.0 & 25.4 & 24.2 & 23.6 & 22.8 & 28.8 & 28.7 & 27.1 & 26.8 \\
\hline & Mol & 10.7 & 11.7 & 12.1 & 13.9 & 8.8 & 9.1 & 9.8 & 10.1 & 26.0 & 24.8 & 24.2 & 23.7 & 29.4 & 29.2 & 27.61 & 27.3 \\
\hline
\end{tabular}

$\mathrm{N} 0=0 \mathrm{~kg} \mathrm{~N} \cdot \mathrm{ha}^{-1}, \mathrm{~N} 1=75 \mathrm{~kg} \mathrm{~N} \cdot \mathrm{ha}^{-1}, \mathrm{~N} 2=150 \mathrm{~kg} \mathrm{~N} \cdot \mathrm{ha}^{-1}$ and N3 = $225 \mathrm{~kg}$ N.ha ${ }^{-1}$; $1=$ Barley, C2= Oats, C3= Rye, C4=Triticale, CP= Crude Protein, $\mathrm{CF}=$ Crude Fiber; Con= Control, FA= Formic Acid, Mol= Molasses; BS= Booting Stage; MDS= Milking Dough Stage.

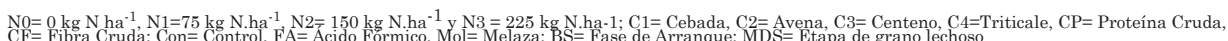


Rev. Fac. Agron. (LUZ). 2021, 38(4):846-866. Octubre-Diciembre.

Jamil et al.

ISSN 2477-9407

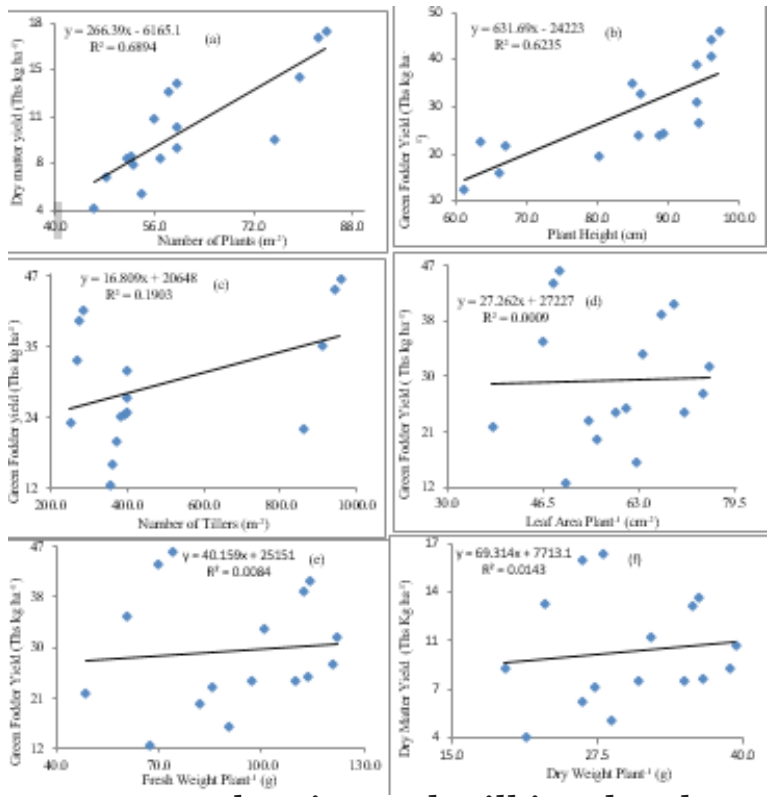

Figure 1. Two years mean booting and milking dough stage association of number of Figure 1. Two years mean booting and milking dough stage association of number of plants, plant height, number of tillers, leaf area, fresh weight plant ${ }^{-1}$ and dry weight. plant $^{-1}$ with green and dry matter yield at Rawalakot, Azad Jammu and Kashmir, Pakistan

Figura 1. Dos años promedio para la etapa de arranque y de grano lechoso para la asociación entre el número de plantas, la altura de la planta, el número de tallos, el área foliar, el peso fresco.planta ${ }^{-1}$ y el peso seco.planta ${ }^{-1}$ con el rendimiento de materia verde y seca en Rawalakot, Azad Jammu y Kashmir, Pakistán

graph was in accordance with Aby et al. (2019) who stated that positive correlation was establish among growth stage at harvest and dry matter level of whole crop wheat while this correlation may differ between years, sites and cultivars. Similarly, Kren et al. (2015) reported that number of tillers exhibited positive correlation coefficient with dry weight per plant and above ground biomass during vegetative de la planta de cultivo. Landry et al. (2019) informaron que los cultivos de cobertura de cereales de invierno como el trigo, el centeno y el triticale, como forrajes de primavera mostraron un aumento significativo de los valores de PC con el incremento de las tasas de $\mathrm{N}$, mientras que, por otro lado, los contenidos de PC disminuyeron a medida que avanzaba el crecimiento desde la fase de hoja bandera hasta la fase de cabeza. El cultivo de cebada se 


\section{Rev. Fac. Agron. (LUZ). 2021, 38(4):846-866. Octubre-Diciembre.}

stage but it may differ significantly during years due to different climatic conditions. Likewise, Gagnon et al. (2019) described that cool season grasses have showed positive quadric and linear response of nitrogen fertilization for dry matter yield.

\section{Conclusion}

The tested winter forage cereals barley, oats, rye and triticale showed best performance with maximum dose of nitrogen application. Among the entire WFCs, the rye gave higher fodder yield at maximum dose of nitrogen application. Furthermore, for winter season, the rye and triticale are the best options to cover up the lean period of green forage availability. Forages preserved at booting stage with the use of molasses is best to get the good quality of silage.

\section{Acknowledgement}

A part of this manuscript has been extracted from $\mathrm{PhD}$ Agronomy thesis of the principal author submitted to the same university.

\section{End of English Version}

\section{Cited literature}

Aby, B. A., A. T. Randby, H. Bonesmo and L. Aass. 2019. Impact of grass silage quality on greenhouse gas emissions from dairy and beef production. Grass Forage Sci. 74(3): 525-534.

Ahmad, A., A. Wahid, F. Khalidg, N. Fiaz and M. Zamir. 2011. Impact of organic and inorganic sources of nitrogen and phosphorus fertilizers on growth, yield and quality of forage oat (Avena sativa L.). Cercet. agron. Molde. 44(3): 39-49 situó por delante de los otros cereales en cuanto a fibra cruda, mientras que el valor más bajo de fibra cruda se observó en el cultivo de centeno (Cuadro 3). La fibra cruda disminuye cuando aumenta el nivel de nitrógeno. El ensilaje conservado mediante la adición de melaza permaneció más elevado en el análisis de la fibra cruda durante los dos años y en ambas fases de la cosecha. Los resultados de estos hallazgos coincidieron con $\mathrm{Li}$ et al. (2016) y Surber et al. (2011) quienes confirmaron que con el aumento de la tasa de aplicación de $\mathrm{N}$ el contenido de FC del ensilaje del cultivo de trigo entero disminuyó. Además, de acuerdo a Morais et al. (2017) el uso de aditivos químicos se justifica para mejorar la estabilidad aeróbica de los ensilados de cereales de alta humedad. El gráfico muestra un aumento lineal del número de plantas con el rendimiento de forraje verde, mostrando una correlación positiva, lo que indica que las plantas más altas tienen el potencial de producir una mayor biomasa.

Además, la asociación entre la altura de la planta y el número de tallos con el rendimiento del forraje verde presentado en la figura 1 también evidenció una correlación lineal positiva entre sí con el rendimiento de forraje fresco, lo que indica la necesidad de mejorar las variedades de forraje, que tengan un mayor potencial para altura de planta y macollas.planta- ${ }^{1}$. La relación individual mostró ser fuertemente positiva mientras que la relación acumulativa con las dosis de nitrógeno mostró una asociación moderada entre las variables. 
Rev. Fac. Agron. (LUZ). 2021, 38(4):846-866. Octubre-Diciembre.

Jamil et al.

ISSN 2477-9407

Los valores de nuestro gráfico de correlación estuvo en conformidad con Aby et al. (2019) quienes plantearon que una correlación positiva se estableció entre las etapas de crecimiento a nivel de cosecha con la materia seca de todo el cultivo de trigo, aunque esta correlación puede diferir según los años, sitios y cultivares. Así mismo, Kren et al. (2015) reportaron que el número de tallos exhibió un coeficiente de correlación positivo con el peso seco por planta y la biomasa sobre el suelo durante la etapa vegetativa, pero puede diferir significativamente durante los años debido a las diferentes condiciones climáticas. Igualmente, Gagnon et al. (2019) describieron que las gramíneas de estación fría han mostrado una respuesta cuadrática y lineal positiva de la fertilización nitrogenada para el rendimiento de materia seca.

\section{Conclusión}

Los cereales forrajeros de invierno evaluados, cebada, avena, centeno y triticale, mostraron el mejor rendimiento con la dosis máxima de aplicación de nitrógeno. Entre todos los cereales forrajeros, el centeno dio un mayor rendimiento forrajero con la dosis máxima de aplicación de nitrógeno. Además, para la temporada de invierno, el centeno y el triticale son las mejores opciones para cubrir el período de escasez de disponibilidad de forraje verde. Los forrajes conservados en la fase de arranque con el uso de melaza son los mejores para obtener una buena calidad de ensilado.

\section{Agradecimiento}

A part of this manuscript has been extracted from $\mathrm{PhD}$ Agronomy thesis of the principal author submitted to the same university.

Una parte de este manuscrito se ha extraído de la tesis doctoral en Agronomía del autor principal, presentada en la misma universidad.

Amanullah, R. A. Khattak and S. K. Khalil. 2008. Effects of plant density and $\mathrm{N}$ on phenology and yield of cereal. Plant. Nut. J. 32: 246-260.

Anwar, A., M. Ansar, M. Nadeem, G. Ahmad, S. Khan and A. Hussain. 2010. Performance of non-traditional winter legumes with oats for forage yield under rainfed conditions. J. Agric. Res.48(2): 171-179.

AOAC. 2012. Association of Official Analytical Chemists. Official method of analysis Waashington, DC.

Bilal, M., M. Ayub, M. Tariq, M. Tahir and M.A. Nadeem. 2017. Dry matter yield and forage quality traits of oat (Avena sativa L.) under integrative use of microbial and synthetic source of nitrogen. J. Saudi Soc. Agric. Sci. 16(3): 236-241.

Dhillon, B. S., R.S. Uppal and M. Goyal. 2019. Forage quality and productivity of barley (Hordeum vulgare L.) as influenced by cutting management under staggered sowing in NorthWest India. Arch. Agron. Soil Sci. $1-15$.

Gagnon, B., N. Ziadi, G. Bélanger, G. F. Tremblay and G. Parent. 2019. Ureabased fertilizer as an efficient nitrogen source in perennial cool-grass forage production. J. Agron. 111(2): 867-880.

Gangwar, H. K. and M.D. Lodhi. 2018. Effect of Nitrogen Levels and Number of Irrigation on Growth and Yield of Wheat. Int. J. Curr. Microbiol. App. Sci. 7(3): 3663-3673.

Geiger, R. 1954. Klassifikation der klimate nach W. Köppen. Landolt-Börnstein- 


\section{Rev. Fac. Agron. (LUZ). 2021, 38(4):846-866. Octubre-Diciembre.}

Jamil et al.

Zahlenwerte und Funktionen aus Physik, Chemie, Astronomie, Geophysik und Technik, 3, 603-607.

Geren, H. 2014. Dry matter yield and silage quality of some winter cereals harvested at different stages under Mediterranean climate conditions. Turkish J. Field Crop. 19(2): 197-202.

Glamočlija, N., M. Starčević, J. Ćirić, D. Šefer, M. Glišić, M.Z. Baltić, R. Marković, M. Spasić, and Đ. Glamočlija. 2018. The importance of triticale in animal nutrition. Veterinary Journal of Republic of Srpska. 18(1): 84-94.

Govt. of Pakistan. 2018. Economic Survey of Pakistan, 2017-18. Ministry of Food, Agriculture and Livestock, Agriculture \& Livestock Division (Economic Wing), Government of Pakistan, Islamabad. Chapter 2, Agriculture: Pp. 1-20.

Iqbal, M. F., M. A. Sufyan, M. M. Aziz, I. A. Zahid, Qamir-ul-Ghani and S. Aslam. 2009. Efficacy of nitrogen on green fodder yield and quality of oat (Avena sativa L.). JAPS.19 (2): 82-84.

Khaliq, A. and M.K. Abbasi. 2015. Improvements in the physical and chemical characteristics of degraded soils supplemented with organic-inorganic amendments in the Himalayan region of Kashmir, Pakistan. Catena, 126: 209-219.

Khan, A., M.H. Anjum, M.K.U. Rehman, Q. Zaman and R. Ullah. 2014. Comparative study on quantitative and qualitative characters of different oat (Avena sativa L.) genotypes under agro-climatic conditions of sargodha, pakistan. Amj. J. Plant Sci. 5(20): 3097.

Kim, K.S., J.D. Anderson, S. L. Webb, M.A. Newell and T.J. Butler. 2017. Variation in winter forage production of four small grain species-oat, rye, triticale, and wheat. Pak. J. Bot. 49(2): 553-559.

Kren, J., K. Klem, I. Svobodová, P. Míša and L. Neudert. 2015. Yield and grain quality of spring barley as affected by biomass formation at early growth stages. Plant Soil Environ. 60(5): 221227.
Landry, E., K. Janovicek, E.A. Lee and W. Deen. 2019. Winter cereal cover crops for spring forage in temperate climates. J. Agron. 111(1): 217-223.

Lekgari, A. L., P.S. Baenziger, K. P. Vogel and D.D. Baltensperger. 2008. Identifying winter forage triticale ( $\mathrm{x}$ Triticosecale Wittmack) strains for the Central Great Plains. Crop Sci. 48: 2040-2048.

Li, C., Z. Xu, Z. Dong, S. Shi and J. Zhang. 2016. Effects of nitrogen application rate on the yields, nutritive value and silage fermentation quality of wholecrop wheat. Asian-Australasian J. Animal Sci. 29(8): 1129.

Malik, P., L.K. Midha, S. Arya and U.N. Joshi. 2015. Effect of cutting and fertility levels on quality of oat. Forage Res. 40: 257-258.

Morais, G., J. Daniel, C. Kleinshmitt, P. Carvalho,J. Fernandes, and L. Nussio. 2017. Additives for grain silages: A review. Slovak J. Anim. 50(1): $42-54$.

Mut, Z., H. Akay and Ö Erbaş. 2015. Hay yield and quality of oat (Avena sativa L.) genotypes of worldwide origin. Int. J. Plant Prod. 9(4): 507-522.

Mut, Z., I. Ayan and H. Mut. 2006. Evaluation of forage yield and quality at two phenological stages of triticale genotypes and other cereals grown under rainfed conditions. Bangladesh J. Bot. 35(1): 45-53.

Obour, A., J. Holman and A. Schlegel. 2018. Seeding rate and nitrogen application effects on spring oat and triticale forage. Kansas Agricultural Experiment Station Research Reports. 4(5),P.5.

Ronga, D., A. Dal Prà, A. Immovilli, F. Ruozzi, R. Davolio and M.T. Pacchioli. 2020. Effects of Harvest Time on the Yield and Quality of Winter Wheat Hay Produced in Northern Italy. Agronomy. 10(6): 917.

Steel, R.G.D., J.H. Torrie and D.A. Dickey. 1997. Principles and procedures of statistics: A Biometrical approach. 3rdzed. McGraw Hill Book Co. New York. pp. 400-428. 
Rev. Fac. Agron. (LUZ). 2021, 38(4):846-866. Octubre-Diciembre.

Jamil et al.

ISSN 2477-9407

Surber, L., H. Abdel-Haleem, J. Martin, P. Hensleigh, D. Cash and J. Bowman. 2011. Mapping quantitative trait loci controlling variation in forage quality traits in barley. Mol. Breed. 28(2): 189-200.

Tawfiq, S. H. E. and S. R. Muhammed. 2014. Response of Three Cereal Crops to Different Clipping Times for Forage Yield at two Locations of Sulaimani Region J. Zankoy Sulaimani.

Worku, M., M. Bänziger, D. Friesen and W.J. Horst. 2007. Nitrogen uptake and utilization in contrasting nitrogen efficient tropical maize hybrids. Crop Sci. 47(2): 519-528.
Zafar, M., M.K. Abbasi and A. Khaliq. 2013. Effect of different phosphorus sources on the growth, yield, energy content and phosphorus utilization efficiency in maize at Rawalakot Azad Jammu and Kashmir, Pakistan. J. Plant Nut. 36 (12): 1915-1934.

Zhang, H., X. Yu, Z. Jin, W. Zheng, B. Zhai and Z. Li. 2017. Improving grain yield and water use efficiency of winter wheat through a combination of manure and chemical nitrogen fertilizer on the Loess plateau, China. J. soil Sci. Plant Nutr. 17(2): 461-474. 